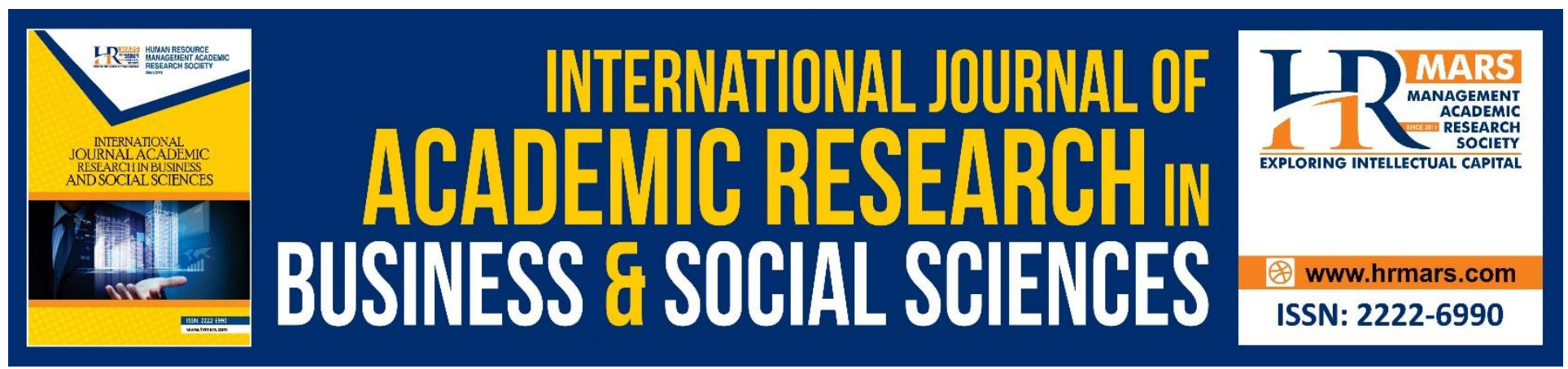

\title{
Children of Cross-Border Marriage: Rights and Future
}

\section{Noraini Md. Hashim, Roslina Che Soh@Yusoff, Nora Abdul Hak, Muhamad Helmi Md Said}

To Link this Article: http://dx.doi.org/10.6007/IJARBSS/v9-i5/5888

DOI: $10.6007 /$ IJARBSS/V9-i5/5888

Received: 13 March 2019, Revised: 02 April 2019, Accepted: 24 April 2019

Published Online: 25 May 2019

In-Text Citation: (Hashim, Soh@Yusoff, Hak, \& Said, 2019)

To Cite this Article: Hashim, N. M., Soh@Yusoff, R. C., Hak, N. A., \& Said, M. H. M. (2019). Children of CrossBorder Marriage: Rights and Future. International Journal of Academic Research Business and Social Sciences, 9(5), 470-480.

Copyright: (C) 2019 The Author(s)

Published by Human Resource Management Academic Research Society (www.hrmars.com)

This article is published under the Creative Commons Attribution (CC BY 4.0) license. Anyone may reproduce, distribute, translate and create derivative works of this article (for both commercial and non-commercial purposes), subject to full attribution to the original publication and authors. The full terms of this license may be seen at: http://creativecommons.org/licences/by/4.0/legalcode

Vol. 9, No. 5, 2019, Pg. 470 - 480

http://hrmars.com/index.php/pages/detail/IJARBSS

JOURNAL HOMEPAGE

Full Terms \& Conditions of access and use can be found at http://hrmars.com/index.php/pages/detail/publication-ethics 


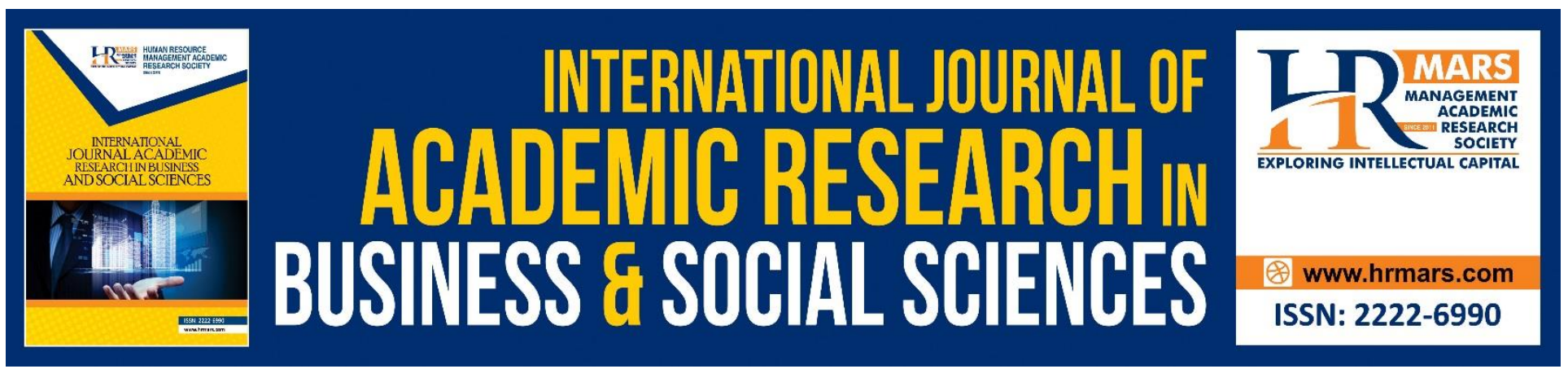

\title{
Children of Cross-Border Marriage: Rights and Future
}

\author{
Noraini Md. Hashim, Roslina Che Soh@Yusoff, Nora Abdul Hak
}

Ahmad Ibrahim Kulliyyah of Laws, International Islamic University Malaysia, Jalan Gombak 53100, Kuala Lumpur, Malaysia

\section{Muhamad Helmi Md Said}

Faculty of Law, Universiti Kebangsaan Malaysia 43600 UKM Bangi, Selangor

\begin{abstract}
In a cross-border marriage (CBM), failure of the Muslim parties to register their CBM will have direct impact to their future born child. Their action will contravene with Articles 3, 5, 7 and 28 of United Nation Convention on Rights of Child that spell out that parents must do what is the best for their children, protect their rights, legally registered their name and right to education. The main purpose of this paper is to address that failure of the CBM couple to register their marriage, no certificate of marriage be produced, will ended up with failure to register the birth. Even if registration of birth is allowed, the name of the biological father will not be stated. Without birth certificate, the child cannot register at public school and lose his right to education. On the other hand, under hukum syara' the child paternity is in doubt and he might lose his right to inheritance if his father died. The study is vital to address to the public the importance of registering their marriage as not to jeopardize their child's future. This paper uses a qualitative data collection method where in-depth document analysis is carried out. Primary sources such as the Acts, Regulations and court's decision are scrutinized. On the other hand, secondary sources that are studied comprise of law reports, legal periodical articles and newspaper cuttings. Possible suggestions are offered in the conclusion.
\end{abstract}

\section{Introduction}

Children are the precious assets of the nation. They are the agents of development and therefore need to be protected and fostered. This can be evidently seen where the government of Malaysia had endorsed the Convention on the Rights of the Child (CRC), introduced the Child Act in 2001 and other relevant laws relating to children. In ensuring that the children are protected under the law, the parents initially must ensure that their marriage must not only be valid by fulfilling the requirement of marriage under hukum syara', but also the requirement and procedures and formalities also registration under the Islamic Family Law Act and Enactments of each States. Crossborder marriage is a marriage that does not fulfill the requirement provided under the said law. If the 
parties failed to register their marriage, the impact is only on them but to the legal status of child will be in question and their rights will be forfeited. Thus, this paper is to highlight the impact of crossborder marriage on the rights and future of children born out of this marriage.

Marriage under Hukum Syara': According to Ahmad al-Khusairi (1976), marriage, which is termed as az-zawaj in the Arabic language refers to marriage or joining together in pairs. It is used to mean marrying as in Surah al-Dukhan verse 54, when Allah says to the effect:

"Moreover, We shall join (zawaj) them to Companion with beautiful, big and lustrous eyes."

The legal definitions by the jurists are quite the same. Jurists unanimously used the terms zawaj and nikah as marriage contract. A more comprehensive meaning of marriage is defined by Qamhani (1980), which is a contract that legalises sexual intercourse between a man and a woman according to hukum shara' and confers rights and duties that come within the marriage.

In terms of formal requirements, according to Wahbah al Zuhayli (1989) the marriage is affected simply by two essential elements of offer (ijab) and acceptance (qabul). Meanwhile, Jamal J. Nasir (1996) stated that declarations which must be made conceptually 'at the same meeting' are pronounced by the parties themselves, or by their representatives (wakil) acting on their behalf, or by their guardians (wali) when they lack the capacity to contract themselves in the marriage. The first speech, from whichever side it emanates, is the offer and the second speech constitutes the acceptance. Muhsin Tayyibji (1968) said that other essential element of a valid Muslim marriage contract, except for the Shia's is the presence of witnesses. It has been said that this element of publicity makes the difference between lawful wedlock and fornication.

The simple contractual form of marriage is almost always accompanied by religious and customary ceremonials. However, as emphasised by Anderson and Coulson (1967) the formalities, which are usually attended upon a Muslim marriage, such as the performance of the ceremony in the presence of a religious official like the Imam of the mosque, are matters of customary practice and in no sense legal essentials.

The above discussion proves that being a civil contract, the validity of a Muslim marriage depends on the conclusion of the marriage contract. If there is a proposal from one side and an acceptance on the other, a valid marriage will come into existence provided that the other conditions of marriage are fulfilled. In understanding the traditional concepts of a Muslim marriage and the simplicity and the informality of the contract do not take account of the need, especially in the complex and highly mobile societies today, to have definitive formal proof of existence of a legally valid marriage. While official registration is considered of paramount importance today, in traditional societies, instead of formal registration, the publicizing of the marriage contract serves as an important safeguard. Further, the public celebration of the marriage through feasting and other social rituals leads to public recognition of the married status of the individuals concerned. In this context, presumptions of marriage have developed in practice. Attempts to introduce registration procedures have met with considerable opposition. The present position in most Muslim countries is that facilities exist for registration of marriages but non-compliance with these merely involves penalties (which differs from one country to another) and does not invalidate the marriage. 
Formalities, Procedures and Registration under Islamic Family Law Act/Enactments: In Malaysia, for a marriage to be given a legal status, it has to fulfil both the requirements under hukum syara' and law under the Islamic Family Law (Federal Territories) Act 1984 (hereinafter known as IFLFTA 1984), specifically for this paper and Enactments of each States.

Prior to the enforcement of the comprehensive Islamic Family law in early 1980s, in the case where the wali refuses to give his permission to the marriage of his daughter, the bride and groom will go to other parts of Malaysia to contract their marriage by the usage of Wali Hakim on the ground that the distance of the place of marriage solemnized from the wali's place is more than two marhalah $(96 \mathrm{~km})$. However, with the enforcement of the new Islamic Family Law Enactments and Act, by virtue of section 20(1) IFLFTA 1984 clearly provides that no marriage shall be solemnized except in the kariah masjid in which the woman resides (section 2), with the Registrar or Shariah Judge giving permission to marry under sections 17 or 18 may give permission for the marriage to be solemnized elsewhere, whether in the Federal Territories or any state. Meanwhile sections 20 (3) (a) and (b) specify that the parties may marry elsewhere other than the kariah masjid whether in the Federal Territory itself or other states provided that the parties obtain permission as under sections 17 or 18 or the proper authority of that state. At the same time, section 28 imposed that the jurunikah (person solemnizing the marriage) must be a person appointed by the YDPA and unauthorized solemnisation is an offence under section 39. Failure to observe the requirement above is an offence being committed under section 40(2) and be fined not exceeding one thousand ringgits or with imprisonment not exceeding six months or with both.

The introduction of the new Islamic Family Law Act and Enactments is the answer to the increasing number of couples marrying without the permission of the authorised body. The question concerning the legal status of the marriage solemnized in Thailand or elsewhere is the main concern of the said authority. Is the Wali Hakim (has the authority to solemnize a marriage in the whole province) or Wali Am (has authority at a specified area only) there a qualified person? Do both parties fulfill the requirement as a husband and wife? Are the witnesses qualified persons? Does the wali really withhold his consent and do the parties fulfill the requirement of two marhalah? Do the parties register their marriage upon coming back to Malaysia? Besides, the increased number of runaway marriages also reflects that the law relating to marriage is so stringent that Malaysians have to turn to Thailand to solve their dilemma. All these and more are problems faced by our government and solutions are needed to curb this act of runaway marriage.

According to Cheha (2007) the validity of the marriage in Thailand is still questionable as Thailand is governed by non-Muslims. Hence, the Muslim affairs are disorganized, and the law imposed is not strict. He also explained that since the Registry of Muslim Marriage is yet to be established any marriage although valid according to hukum shara' is not registered. However, it is prescribed under section 26 (10) of the Administration of Islamic Organization Act 1997 that the Provincial Islamic Commission has the authority to issue letters of recommendation to Muslim and not to register it. As a result, there is a possibility that the marriage certificate issued by them is not recognized or cannot 
be certified as an original certificate. Moreover, the status of a few of the wali or the jurunikah is also questionable as to whether they are qualified and appointed by the authorized body or not. This is because, due to the vulnerable position of the parties to marry, the opportunity is seized by certain marriage syndicates to conduct their marriage without concern whether the marriage is valid under hukum shara' or procedural law. As an assurance, the syndicate will provide the couple with fake certificates, which is discovered only when they decided to register their marriage. In the worst scenario, there are couples who claim that they have marriage certificate issued by the said religious council or religious committee in Thailand even though their marriage was conducted in Malaysia (Cheha ,2007).

Procedure of marriage in Malaysia can be divided into two categories, i.e. procedure of marriage within and outside Malaysia. For the preliminaries of marriage (namely marriage within the state), the future bride and groom must go through an Islamic pre-marriage course which is known as PreMarriage Module (Modul Bersepadu Kursus Pra-Perkahwinan Islam), which was collaboratively designed by the relevant government agencies together with the Islamic Department of each state in Malaysia. This requirement was decided in the Head of Islamic Department States Council Meeting (Majlis Persidangan Ketua-ketua Jabatan Agama Islam) ("Rumahku SyurgaKu Programme" (Hashim, 2003). It is implemented to ensure that both the bride and groom to be have adequate fundamental knowledge in religion and other basic requirements in marital life. However, for those who had married earlier, they do not have to undergo this course. After the completion of this course, which normally takes a period of two days, each participant will be given a certificate, which is the essential requirement in the application of marriage later. In addition, starting from year 2005, as initiated by the Islamic Department of Johore (which was later followed by the rest of Islamic Departments in Malaysia) the introduction of HIV screening program was introduced.

\section{What is Cross-border Marriage (CBM)?}

Generally, the term CBM or runaway marriage (can be used interchangeably) refers to an act of marriage that is not recognized by customs, law and religion. Hashim (2003) stated that the layman normally terms it as kahwin lari or kahwin koboi (cowboy marriage) as to the irregular nature of marriage solemnizes. As to the legal definition, it is not being define under the Islamic Family Law Act or Enactment. However, Hashim (2006) stated that it can be concluded from interviews carried out with the Shariah Judges, Registrars and Assistant Registrar of several states religious offices as a marriage without the consent of the Registrar of Marriage, Divorce and Rujuk and the Shariah judge particularly in cases involving polygamy. (Personal communication by Noraini Md Hashim with Y.A .Ustaz Fauzi, Shari'ah Judge of Shari'ah Lower Court Gombak, Selangor, 17 April 2006 and Y.A. Sheikh Amiruddin Putera Bin Zainol Abidin, Shariah Judge of Shariah Lower Court Pendang and Kota Setar, Kedah, 9 April 2006). The term runaway marriage denotes not only to marriage solemnised abroad without the permission of the state religious office or Shariah court, but it also involves any marriage solemnise in any part of Malaysia too (Noraini, 2003).

Kahwin lari is not only practised by the ordinary people, but by people coming from different backgrounds involving the rich (Poligami: Speaker Kelantan terlepas hukuman penjara, 1999) and the 
poor; politicians as in the case of Wan Abdul Rahim Wan Abdullah, the Kelantan State Assembly Speaker who is married to his second wife (a Cambodian girl) without the court's permission in Cambodia (Poligami: Speaker Kelantan terlepas hukuman penjara, 1999); professionals as in the case of Tan Sri Zaki Azmi, (a famous lawyer as he was then) who was married through a marriage syndicate to his second wife Nor Hayati Yahaya, a manager, at a textile shop in Perlis (Sah, 2006), the royals as in the case of an ex-Chief Minister of Selangor and the princess of the late Almarhum Sultan of Selangor who were married in Southern Thailand via Sungai Kolok (Golok) (Taib, 2006); educated and non-educated, businessman, students etc. The couples who commit this act can also be categorized as local couple (both who are Malays) and between a local (male or female Malay) with non-local party (normally with female or male Indonesian or female Malay with a Bangladeshi man).

The most common reasons for CBM are refusal of the wali to give his consent to the marriage and husband who wishes to practice polygamy without the wife's knowledge. Other reasons include parties who had committed fornication or adultery (zina), guilty due to close proximity (khalwat), pregnant outside wedlock, to marry during period of iddah, failure in marriage course, failure in HIV screening and the excessive amount of hantaran. On the rise are cases of getting a PR (permanent resident) status or to get a working permit by the immigrants. (Harian Metro, Sanggup kahwin nenek demi PR, 2006)

\section{Methodology}

This paper uses a qualitative data collection method where in-depth document analysis is carried out. Primary sources such as the Acts, Regulations and court's decision are scrutinised. On the other hand, secondary sources that are studied comprise of law reports, legal periodical articles, online newspaper and newspaper cuttings.

\section{Results}

Rights of Children in Malaysia: Children's rights in Malaysia have progressed since Malaysia acceded to the Convention on the Rights of the Child (CRC) in 1995 and introduced the Child Act in 2001. Government and civil society initiatives to realise and uphold the rights of children have resulted in progress in the field of education and primary healthcare for children. The Government of Malaysia's ratification of the CRC contains a number of conditions in the form of reservations which allow the Government to disagree with a provision in the CRC. Malaysia has five reservations currently, namely: Article 2 on non-discrimination; Article 7 on name and nationality; Article 14 on freedom of thought, conscience and religion; Article 28(1) (a) on free and compulsory education at primary level; and Article 37 on torture and deprivation of liberty (the CRC Articles were said to not conform to the Constitution, national laws and national policies of the Government of Malaysia, accessed 2017). This paper however will focus only on matters pertaining to the rights of Muslim children to register birth, education, ascription of paternity, legitimacy and maintenance.

Right to Register Birth: Birth registration is the fundamental right of a child. In Malaysia, the Birth and Death Registration Act 1957 (Amendment 1983) (hereinafter known as BDRA 1957) together with National Registration Department (hereinafter known as NRD) will furnish matters relating to 
registration of birth. Birth registration is a fundamental right of every child and the child will be in great difficulty if the parents did not register their marriage (Kelahiran, 2017). It is estimated that there are 50,000 undocumented children in Malaysia (Undocumented and stateless children in Malaysia, accessed 2017). Besides children born without parents registering their marriage and children born out of wedlock, children from the rural poor and indigenous communities in remote locations, particularly in Sabah and Sarawak as well as children of irregular migrants and refugees. (Report on children's right, 2017)

Right to Education: Education in Malaysia is overseen by the Ministry of Education. Although education is the responsibility of the Federal Government, each state and Federal Territory has an Education Department to co-ordinate educational matters in its territory. The education system is divided into preschool education, primary education, secondary education, post-secondary education and tertiary education. Education may be obtained from the multilingual public-school system, which provides free education for all Malaysians, or private schools, or through homeschooling (National education system, 2017).

In Malaysia, primary education was made compulsory starting from the school term beginning in 2003 through an amendment made to the Education Act 1996 in 2002 (Education (Amendment) Act 2002). Under the new provisions, a duty is imposed on every parent who is a Malaysian citizen residing in Malaysia to ensure that if his child has attained the age of six years on the first day of January of the current school year that child is enrolled as a pupil in a primary school in that year and remains a pupil in a primary school for the duration of the compulsory education (Admission of pupils to school, accessed 2017). To be admitted at a school for a citizen student, according to the online application under Ministry of Education, requires the parents among others to furnish the student's birth certificate and/or identity card and parents' identity card and marriage certificate during the registration of admission of the pupil to the school (Registration of Year 1 Students 2017/2018 Intake, 2017).

Ascription of Paternity and Legitimacy: For a child to gain valid paternity, the laws require that the child must be born within marital bondage as in Surah al-Furqan: 54:

"It is He who has created a man from water, then has He established relationship of lineage (nasab) and marriage: for Thy Lord has power over all things".

Islamic law relating to legitimacy of a child and acknowledgement of paternity in Malaysia is governed by the Islamic Family Law Federal Territories Act 1984 and Enactments of other States which is in line with the provision of hukum syara'. Sections 2 of IFLFTA 1984 defined the word nasab (paternity) as descent based on lawful blood relationship, while section 110 provided the determination of the legitimacy of a child is a child born 6 months after the date of the marriage as discussed in the case of Mohd Faizol bin Zainal v Suhaila bt Yusoff [2014] 2ShLR 83. In determining what is lawful blood relationship in the marriage, the parties must prove that the marriage not only fulfil the requirement of hukum syara' as under sections 11 and 12 but the marriage must also observed the requirement under the said law and registered as provided under sections $25,6,28$ and 34 . With regard to the 
child who is born after the dissolution of the marriage, for a legitimate status, under section 111 , the child must be born within four years of the dissolution. This is perceived as being for the protection of nasab of the child born out of the marriage. This issue was deliberated in the case of Fatimah bt Abdullah and Anor v Mat Zin bin Kassim [2001] 14 JH (2) 225. If a child is born out of a (doubtful) syubhah intercourse, particularly involving CBM, section 113 provides legitimate status provided that the child is delivered within the period of six qamariah months to four qamariah years after intercourse, but the marriage status will be declared as invalid. This is clearly deliberated in the case of Ismail v Aris Fadhillah [1980] JH5 326.

Then again, the National Fatwa Committee meeting No 64, July 27, 2004 has defined illegitimate child as a child born out of wedlock (adultery or rape) and not from doubtful intercourse and a child born less than six months and two seconds from the date of sexual intercourse. The illegitimate child cannot ascribe to the man responsible to his birth or anybody declared to be his father.

Maintenance: Unanimously, the Muslim jurists agreed that children are those who are entitled to maintenance under hukum syara'. Based on section 70 of IFLFTA 1984, the duty to provide maintenance is foremost and duly imposed upon the father and he will not share the responsibility with anyone else. According Ibrahim \& Mohd (2007), the duty is due to kinship (qarabah) that exists between the father and children, which is based on blood and lineage relationship which is clearly stated in al-Baqarah: 233 (al Quran). By virtue of sections 72 (1) and 73 (1) (2) the father responsibility to provide maintenance to his children are not only those under his custody, but also those under the custody of other person namely the mother of the children or other relative whether in marriage or after the dissolution of marriage.

\section{Discussion}

The Effect of Cross Border Marriage on Children: The effect of CBM will not be felt until and unless the parties of CBM faced matrimonial difficulties. The court will not have jurisdiction to entertain their case for an order of divorce or an order pertaining to divorce or matrimonial relief until and unless the parties can prove to the Syariah Court that marriage is registered or deemed to be registered under IFLFTA 1984, or the marriage was contracted in accordance with hukum syara' and whether either of the parties resides in Federal Territories at the time the application made as provided under section 45. As such, if the parties failed to prove their marriage is valid according to hukum syara' and failed to register their marriage, the impact will be on the child born out of the marriage. If the parties decided to register later from the date of the marriage solemnization, there are two possible consequences. By virtue of section 12 (2) IFLFTA 1984, if the marriage is valid according to hukum syara' but not registered as on the solemnization of the marriage, the marriage is nevertheless valid and subject to penalty. However, under section 40 if the marriage is void according to hukum syara' but is nonetheless registered the person who registered the marriage may have committed an offence and the marriage remains invalid and (separation) will be ordered and penalized too. If the parties decided not to register at all, no legal status will be conferred and status of marriage under hukum syara' is indeterminable. Therefore, if marriage is not registered, no 
marriage certificate will be given, and this is the crux of the problem that will affect not only the parties but the children too.

Certificate of birth: As earlier mentioned, if the parents are without marriage certificate due to failure to register their CBM marriage and fulfilment of the conditions specified by the NRD, a birth certificate will not be granted. In some cases, although birth certificate is given but the name of the father in the form will be blank until and unless marriage certificate be produced later. Children without a birth certificate can be denied access to public healthcare and other basic public social services, which expose them to exploitation and poor health. Besides that, lack of a birth certificate can also affect the children chances of applying for a MyKad when they reach 12 years of age. Failure to have Mycard will end up with difficulty to find proper job and to travel abroad. In Jalinan Mesra Outreach 2017 programme by the State of Kedah Education Department with Kedah National Registration Department (NRD) had discovered quite a few illegal marriages, late registration of births due to the lack of adequate documentations, especially if there is no marriage registration certificate or nationality verification, family problems and others are among the highest cases received for those without birth certificate.

Although the Education Amendment Act 2002 has made primary education compulsory for all children from aged 6, this requirement is not enforced. There are an estimated 200,000 children of primary-school age in Malaysia who are not attending free primary education in government-run schools including children without birth certificates who are denied this opportunity mainly because their parents failed to register their CBM marriage in the initial place. Not attending school, means they are losing opportunity to learn and acquire knowledge, to be able to become a better person, to mix with children of their own age and losing many social skills. In one unreported case a grandfather from Kulim, said he was worried about the fate of his three grandchildren who were faced with difficulties in schooling due to failure to produce birth certificates. He said that the grandchildren were forced to leave school after the school administrators asked them to provide the document. Various attempts have been made to obtain the birth certificate of his three grandchildren but without avail since their parents illegally married and did not register the marriage (Kelahiran, 2017).

In another unreported case, Shasa Natasha, 10; Noramira Natasha, 9; dan Mohd. Aidil Fitri, 8; were unable to enroll to school as the parents failed to provide their birth certificate. Since not schooling, the children are of very low self-esteem and timid. The father had in 2001 enquired about the status of application for birth certificate of his children but the NRD official answered that since the parents' marriage certificate is not valid, the NRD cannot provide them with the birth certificate as the status of marriage is doubtful. He was also told to pay a penalty of RM2000 for his wrongdoing and remarried with his wife (Sijil nikah halang hasrat persekolahan 3 beradik, accessed 2017).

Ascription of paternity (nasab) in relation maintenance, inheritance, guardianship and others: Section 2 of IFLFTA defines nasab as "descent based on lawful blood relationship" which is in line with the meaning Surah al Furqan: 54 that is paternity is only established through valid marital bondage. In relation to CBM, failure to register the marriage will lead to the status of the child be illegitimate 
if the parties in question realized and were aware of the fact that their marriage was against the procedure and hukum syara'. In addition, the court wished to protect the interest of Muslims by discouraging this CBM as discussed in the case of Re Mohd Fairus bin Othman \& Ita Wijaya bt Ismail [2009] 28JH (2) 203. If the child paternity is not validly ascribed to his lawful father, the child will be disqualified to acquire maintenance and even inheritance if death occurs. Specifically, for a female child, if the paternity cannot be established in her putative father, the father cannot act as her guardian in marriage (wali an-nikah). All the complications which are to be faced by the children of CBM is confirmed by the Director of Jabatan Agama Islam Selangor (JAIS) in the Jom Daftar Nikah programme which is held from 1 August -1 November 2017. The programme is specially catered to assist parties whose marriage is void failure to fulfil requirement under the provision of Islamic Family Law Enactment of Selangor 2003 (Nikah, 2017).

\section{Conclusion}

A marriage conclusively must have adhered to the requirements laid down by hukum syara' and procedure and formalities under the Islamic Family Law Act/Enactments to confer it with legal status. Without it, the parties affected are not only the parties of CBM themselves, but also their children. The rights of children are affected, and their future is jeopardized. The immediate effect is when the parties of CBM failed to register their marriage resulting to failure to register the birth. This will lead to other important events of the children life starting with no ascription of paternity due to birth not registered, losing the right to be admitted in school, to apply for Mycard, difficulties in searching for formal job, disqualification to get maintenance and many more. Although, there are provisions to penalise the offenders of CBM, enforcement should be at full force to ensure that others are afraid to commit the same offence. Community service at orphanage, rehabilitation centre for young people, old folk home and as such should be introduced on the offenders to make them responsible to people closed to them. Finally, the relevant authorities like JAKIM and JAIS should come out with more programme to expose to the public the importance to abide both the law under hukum syara' and Islamic Family Law Act/Enactments to ensure that the welfare and the wellbeing of the children are protected.

\section{Corresponding Author}

Noraini Md. Hashim, Ahmad Ibrahim Kulliyyah of Laws, International Islamic University Malaysia, Jalan Gombak, 51300 Kuala Lumpur, Malaysia, Email: norainim@iium.edu.my

\section{References}

Administration of Islamic Organization Act 1997

Al-Khusari, A. (1976). Al-Nikah wa al-Qaddaya al-Muta alliqah bihi, Dar Ibn Zaydun, Beirut, 7.

Al-Zuhayli, W. (1989). Al-Fiqh al-Islami wa Adillatuh, 3rd Publication, Damascus: Dar al-Fikr, 7: 78

Al-Qur'an: Surah al-Baqarah (2): 233.

Ainsafree Bidin, Sijil Nikah Halang Hasrat Persekolahan 3 Beradik, utusanperak@utusan.com.my (Accessed on 23 September 2017).

Harun, A. (2006). Zaki Azmi mohon isytihar pernikahannya tak sah.

http://www.utusan.com.my/utusan/archieve. (Accessed on 2 March 2006). 
INTERNATIONAL JOURNAL OF ACADEMIC RESEARCH IN BUSINESS AND SOCIAL SCIENCES

Vol. 9, No. 5, May, 2019, E-ISSN: 2222-6990 @ 2019 HRMARS

Anderson, J. N. D. and Noel, C. (1967). Islamic Law in the Contemporary Cultural Change, Saeclum, p. 62.

Children Rights Coalition Malaysia, https://unicef.org/eapro/Report_on_Children_Rights_pdf. (Accessed on 23 September 2017).

Cj.my/post/81519/research-50000-undocumented-and-stateless-children-in-malaysia (Accessed on 23 September 2017).

Education (Admission of Pupils to Schools, Keeping of Register and Conditions under which Pupils May be Retained in Schools) Regulations 1998. (Accessed on 23 September 2017).

http://www.espact.com.my/national-education-system/compulsory-primary-education.

(Accessed on 23 September 2017). http://www.sinarharian.com.my/edisi/utara/lapan-kestiada-sijil-kelahiran-(Accessed on 23 September 2017).

http://www.islam.gov.my/e-rujukan/islammas.html (Accessed 20 September 2017).

Islamic Family Law (Federal Territories) Act 1984

Tayyibji, M. (ed). (1968). Muslim Law: The Personal Law of Muslims in India and Pakistan, 4th Edition, N.M. Tripathi, Bombay, p. 54.

Hashim, N. M. (2003) Kahwin lari: Tinjauan umum (Runaway marriage: A general overview). Paper presented at the Seminar Isu-isu Mahkamah Shariah IV; Kahwin Lari: Masalah dan penyelesaiannya, Moot Court, International Islamic University Malaysia.

National laws and national policies of the Government of Malaysia, including the Syariah law, https://treaties.un.org (Accessed on 22 Sept 2017).

Poligami: Speaker Kelantan terlepas hukuman penjara, Utusan Malaysia, 21 July 1999, p 4.

Qamhani, Hamid, M., Allah, U. A. (1980). Ahkam al-Ahwaql al-Shakhsiyyah li al-Muslimin, Dar alMatbu'ah al-Jariah, al-Iskandariyyah, 21.

Registration of Year 1 Students 2017/2018 Intake, https://public.moe.gov.my/ (Accessed on 23 September 2017).

Taib, T. A. B. M. (2006). KenyataanMedia.http://www.freeanwar.net/jan 2000 (Accessed on 8 February 2006). 